\title{
冷中性子ディスクチョッパー型分光器 AMATERAS
}

中島 健次，河村 聖子

(J-PARC センター 物質・生命科学ディビジョン 中性子利用セクション)

\section{AMATERAS - The Cold-Neutron Disk-Chopper Spectrometer}

\author{
Kenji Nakajima, Seiko Ohira-Kawamura
}

Neutron Science Section, Materials \& Life Science Division, J-PARC Center

\section{0}

\begin{abstract}
AMATERAS is a cold-neutron disk-chopper spectrometer newly constructed in Materials and Life Science Facility in J-PARC. By combination of high-peak intensity from a $\mathrm{H}_{2}$-coupled moderator source and high-speed disk-choppers for both pulse shaping and monochromating, the spectrometer is designed to realize both high-resolution $\left(\Delta E / E_{\mathrm{i}}=1 \% @ E_{\mathrm{i}}=20 \mathrm{meV}\right)$ and high-intensity with high flexibility in cold-neutron region. Construction of AMATERAS has been completed in this spring and the spectrometer is now in commissioning phase.
\end{abstract}

Keywords: J-PARC, Chopper Spectrometer, Disk Chopper, Cold Neutron

1. アマテラス

アマテラス[1]（Fig.1）は，物質・生命科学実験 施設（MLF）の中性子非弾性散乱装置の中で，比 較的低い数十 $\mu \mathrm{eV}$ から数十 $\mathrm{meV}$ のエネルギー領 域を受け持つディスクチョッパー型分光器である. J-PARC の中性子源の高強度を享受しつつ高いエ ネルギー分解能と高い測定の自由度を持つ非弾性 散乱装置である。その名前は，装置のそのような 特徵から測定の対象亡なる現象を「あまねく照ら す」，「あまた照らす」というところに由来する。 分光器の検討は 2003 年以前から行われ，2005 年 には実験装置設置詳細計画書が当時の実験装置計 画検討委員会（現在の中性子実験装置部会）に承 認された。 そして，2006 年度には日本原子力研究

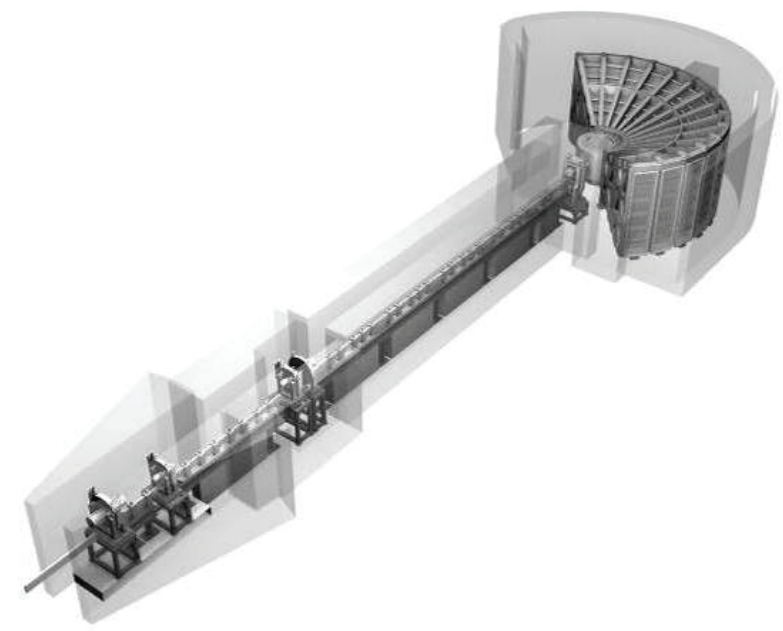

Fig.1 A 3D image of AMATERAS.
開発機構の装置として建設予算が認められ，3 年 間の建設期間を経，2009 年春に完成した。

アマテラスは、高分解能と高強度を実現するた めに，パルス整形チョッパーを装備したマルチチ ヨッパー型分光器という形式を選択している. 分 光器は, 線源としてピーク強度の高い結合型減速 材を選択している。J-PARC, MLF の結合型減速 材は，特に $20 \mathrm{meV}$ 以下の低エネルギー領域では， 非結合型減速材の 1.5 倍から 2.5 倍の高いピーク強 度を持つ。もちろん, 結合型減速材はそのままだ とパルスの時間幅や遅い時間まで続くテールが高 いエネルギー分解能実現に不利になる. そのため, 試料近傍の単色化用チョッパーと共に線源の近傍 に同等の性能を持つもう 1 台のチョッパーを配置 し，それらを通して中性子ビームを試料に入射さ せることで，結合型減速材の高強度のピーク部分 だけを非結合型減速材に勝るような綺麗な形で切 り出して使用しようというのがこの分光器のコン セプトである (Fig. 2).チョッパーの開口時間を 最適化することで，実験条件に合わせて強度と分 解能を広い範囲で最適化できる高い自由度もこの 分光器の特徵である. 同様の思想で作られた分光 器には, アマテラスの他, ISIS 第 2 ターゲットス テーションの LET, SNS の CNCS がある.これら は，アマテラスと同時期に計画され，アマテラス 同様，最近相次いで稼働を開始している.

さらにアマテラスでは，四季や DNA でも取り 入れている複数の入射中性子エネルギーを同時に 利用して高い測定効率を実現する測定手法である Repetition Rate Multiplication（RRM）にも対応して 


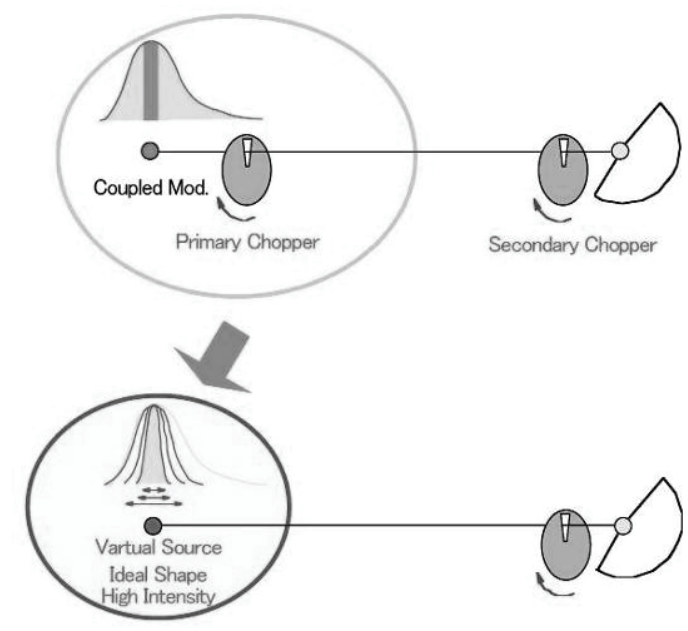

Fig.2 Schematic image of the concept of a chopper spectrometer with a pulse shaping chopper.

いる. 3 組の高速ディスクチョッパーは，全てを 協調的に運転した場合でも複数個の入射中性子工 ネルギーが取り出せるように，それぞれの線源か らの距離について正確に 1:2:4 の比になるように 設置されている. また，この目的のためにはでき るだけ広いバンド幅の中性子が通り抜けられるよ うにしなくてはならない。高速ディスクチョッパ 一のディスクの周速は，アマテラスが扱うエネル ギ一領域の中性子ではその速度と同程度になる。

特に，2 枚のディスクを組みにして互いに逆方向 に回転させて開口時間を短くしている（CounterRotating) アマテラスの高速ディスクチョッパーの 場合，中性子がきちんと通り抜けられるように，2 枚のディスクの間を通過する中性子の飛行時間に 合わせて互いのディスクの位相差をずらす必要が ある．位相差は，ある特定の速度の中性子に対し て最適化されるが，一方で，RRM で複数の入射工 ネルギーを利用する場合，広いエネルギー範囲の 中性子が一度に利用できないと都合が悪い、その ため，最下流のディスクチョッパーは， 2 つのデ イスクの厚みがある回転中心部を上下にずらし互 いのディスク先端部分を接近させてディスク間の 飛行時間を短くして，そのような最適な位相差の 違いを小さくし，広いバンドの中性子が十分な強 度で通過できるように工夫している[2].

アマテラスの主要なパラメーターを Table 1 に 示す. 線源-試料間距離, 試料-検出器距離は, 達 成できる最高分解能と試料位置での強度を最適化 することで決定された值である。検出器は, でき るだけ多くの立体角を覆うことを目標とし，散乱 真空槽やそれを納める遮蔽体について, 運用上の 利便性や製作の困難さ, コストなどを睤んだ上で, この範囲となり，0.67 Sr をカバーする. アマテラ スで多くの需要が見込まれる非晶質，ソフトマタ 一などの研究から要請されるであろうできるだけ 大きな $Q$ の測定が可能なように，水平方向には 180分のスパンを確保した上で高い散乱角までカ バーするようにした。この設計で， $E_{\mathrm{i}}$ がアマテラ スでもつとも得意な領域となる $20 \mathrm{meV}$ より低い
Table 1 Characteristic parameters of AMATERAS

\begin{tabular}{|c|c|}
\hline Moderator & Coupled $\mathrm{H}_{2}$ (BL14) \\
\hline Flight Path & $\begin{array}{l}L_{\text {moderator-sample }}=30 \mathrm{~m} \\
L_{\text {sample-detector }}=4 \mathrm{~m}\end{array}$ \\
\hline Incident Energy & $\begin{array}{l}1-80 \mathrm{meV} \\
\text { (at its best @1 20 meV) }\end{array}$ \\
\hline Energy Resolution & $\Delta E / E_{\mathrm{i}} \geq 1 \% @ E_{\mathrm{i}}=20 \mathrm{meV}$ \\
\hline Scattering Angle & $\begin{array}{l}\text { Horizontal: }-40^{\circ} \sim+140^{\circ} \\
\text { Vertical: }-16^{\circ} \sim 22^{\circ}\end{array}$ \\
\hline Fast Disk-Choppers & $\begin{array}{l}\text { Radius: } R=300 \mathrm{~mm} \\
\text { Revolution: } f \leq 350 \mathrm{~Hz} \\
\text { No. } 1 \quad\left(L_{\text {moderator-chopper }}=7.1 \mathrm{~m}\right) \\
2 \text { disks (Counter-Rotating) } \\
\text { Slit width: } 30 \mathrm{~mm} \\
\text { No. } 2\left(L_{\text {moderator-chopper }}=28.4 \mathrm{~m}\right) \\
2 \text { disks (Counter-Rotating) } \\
\text { Slit width: } 10 \& 30 \mathrm{~mm} \\
\text { No. } 3\left(L_{\text {moderator-chopper }}=14.2 \mathrm{~m}\right) \\
1 \text { disk } \\
\text { Slit width: } 30 \mathrm{~mm}\end{array}$ \\
\hline Slow Disk-Choppers & $\begin{array}{l}\text { Radius: } R=300 \mathrm{~mm} \\
\text { Revolution: } f=12.5 \& 25 \mathrm{~Hz} \\
\text { Opening angle } 0-175^{\circ} \text { (variable) } \\
L_{\text {moderator-chopper }}=9 \mathrm{~m} \& 13.7 \mathrm{~m}\end{array}$ \\
\hline Beam Transport & $\begin{array}{l}3 Q_{\mathrm{C}} \& 3.8 Q_{\mathrm{C}} \text { Supermirror } \\
\text { Curved Section: } L=19.6 \mathrm{~m}, R=2 \mathrm{~km}\end{array}$ \\
\hline Detector System & $\begin{array}{l}{ }^{3} \mathrm{He} \text { 1D-PSD } \\
448 \text { tubes (at the full installation) } \\
\phi=1 \text { inch, } L=3 \mathrm{~m}, p=10 \mathrm{~atm}\end{array}$ \\
\hline
\end{tabular}

エネルギーで $\Delta E / E_{\mathrm{i}}$ が最小で $1 \%$ を切る。 また，試 料位置での中性子束では， $\Delta E / E_{\mathrm{i}}=1 \%$ 時では, $10^{4} \sim 10^{5}$ (neutrons $/ \mathrm{cm}^{2} / \mathrm{sec}$ )， $\Delta E / E_{\mathrm{i}}=3 \%$ の条件で $10^{4} \sim 10^{6}$ (neutrons $/ \mathrm{cm}^{2} / \mathrm{sec}$ ) 程度になると予想される

(いずれも $1 \mathrm{MW}$ 時). 分解能共々これら分光器 の設計上の性能が実現されているかどうかは現在 コミッショニングにおいて機器調整を重ねながら 検証を行っているところである.

\section{2. アマテラスの機器}

アマテラスは, 多数の機器より成り立っている. これらの中でも主なものについて紹介していくこ とで, 装置としてのアマテラスの概略を示したい.

\section{1. ディスクチョッパー}

アマテラスの心臓部と言えるのが，ディスクチ ヨッパーである. 線源から $7.1 \mathrm{~m}$, および, $28.4 \mathrm{~m}$ の位置に置かれたそれぞれ 2 枚組のディスクを持 つ高速ディスクチョッパー2 台がパルス整形チョ ッパーを持つチョッパー型分光器としてアマテラ スを成立させている主チョッパーである.さらに， RRM を用いる際に問題になる線源のパルスの遅 い時間の部分からくる漏れを除去するために，1 枚ディスクの高速ディスクチョッパーが，線源か ら $14.2 \mathrm{~m}$ の位置に置かれている.

アマテラスでは, $E_{\mathrm{i}}=20 \mathrm{meV}$ 以下の領域で $1 \%$ ま でのエネルギー分解能を出せることが求められて いた。 そのためには， $8 \mu$ 秒以下の開口時間を実現 


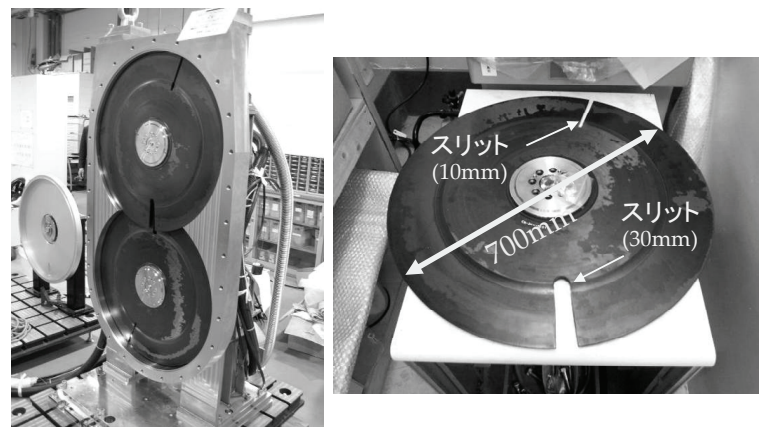

Fig.3 A fast disk chopper (No. 2) (left) and a disk (right) of AMATERAS.

する必要があった。直径 $700 \mathrm{~mm}$ のディスクで 1 $\mathrm{cm}$ 幅のスリットを持ったディスクチョッパーで この開口時間を実現するためには, $350 \mathrm{~Hz}$ という 回転速度が必要となる。その時, ディスクの周速 は $780 \mathrm{~m} / \mathrm{s}$ にも達し，ディスク内部は，170,000G 以上の加速度に耐えなくてはならない. アマテラ スが計画された時，これだけの性能を持つディス クチョッパーは世界に存在しなかった. 2004 年か ら開始された開発は, 何枚もの試作ディスクやチ ヨッパー本体の破損を繰り返しながら, 最後はつ いに目標とする $350 \mathrm{~Hz}$ 回転に耐えられるディス クを製作することができ，アマテラスに装備された。

アマテラスには, 高速ディスクチョッパーの他 に 2 組の $25 \mathrm{~Hz}$ ，あるいは， $12.5 \mathrm{~Hz}$ で回転する低 速チョッパーが装備されている. アマテラスの低 速チョッパーには, 通常の飛行距離が長い装置で 求められるフレームオーバーラップを除去する機 能と, RRM 等の運用で必要とされる狙った波長帯 を取り出すバンドチョッパーとしての機能とが求 められ，アマテラスの多彩な実験モードに合わせ た多様な運用が求められる。 そのため, アマテラ スの低速チョッパーは，互いに同方向に回転する $175^{\circ}$ の切り欠き部を持ったディスク 2 枚が 1 組と なっており，互いの位相の差を調整することで, 実効的な開口角度が $0^{\circ}$ から $175^{\circ}$ まで変化させる ことができ，柔軟な運用に対応する.

\section{2. 真空散乱槽}

アマテラスの真空散乱槽は, 容積が $59 \mathrm{~m}^{3}$, 差し 渡し $8.5 \mathrm{~m}$, 高さ $3.6 \mathrm{~m}$ と MLF の中でも HRC や NOVA と並ぶかなり大きな真空タンクである。ア マテラスでは, 四季などと同様, 検出器を真空槽 内に配置し, 試料から検出器まで何も遮りものの ない一体の真空槽をな寸形を採用している．その ため, 真空槽は, 冷凍機等の断熱真空槽の代わり にも用いられる。この真空槽は，粗引き用の大型 のルーツポンプ付きスクリューポンプ (エリコン ライボルトバキューム社製 SCREWLINE SP630F

(RUVAC WSU2001 付き)) 2 系統と大容量のクラ イオポンプ（エリコンライボルトバキューム社製 COOLVAC 30.000) の組み合わせで $5 \times 10^{-5} \mathrm{~Pa}$ 以下 の真空度まで到達することができる．アマテラス の真空槽は, 2008 年夏に 3 分割されて東海村に運 ばれ，MLFにほど近い建物内で最終的な組み立て
と真空試験が行われた後, MLF の実験ホールに搬 入された (Fig. 4). 据え付けられた後, 内壁はカ ドミウムで内張され, 検出器や真空排気系が据え 付けられた。

\section{3.ガイド管}

アマテラスのビーム輸送系は，スーパーミラー ガイド管で構成され，試料位置でできるだけ低い バックグラウンドとできるだけ高い中性子線束を 実現するように設計されている[3]. 水平方向の形 状は，線源での即発 $\gamma$ 線や高いエネルギーの中性 子を取り除き低バックグラウンドを実現するため に, 曲率 $2 \mathrm{~km}$ の曲導管となっている. 一方で, 垂直方向の形状は, 試料位置での線束をできるだ け高めるように設計されている，少ない反射で効 率よく試料位置に中性子を集束させることのでき る楕円形状を出発点として, 注意深くシミュレー ションを行い, 最終的には, 直線部分, 楕円分, そして，その間に直線部と楕円部をなめらかにつ なぐ遷移部分を組み合わせた形状となっている. さらにコストと製作期間をできるだけ押さえるた めに, スーパーミラーの臨界指数について最適化 を行った結果, 大部分は $3.0 Q_{\mathrm{c}}$ ミラーを用い, $3.8 Q_{\mathrm{c}}$ のミラーは, 曲導管の外周側と下流の収束部分な どごく限られた部分だけで済ませることができた。 アマテラスのガイド管のスーパーミラーは, 当初 J-PARC センター内で製作されたミラーのみでま かなう予定であったが，コストや製作期間の最適 化を進めていった上で, $3.0 Q_{\mathrm{c}}$ ミラーなど比較的安 価な部分については外部から購入する形で調達さ れた. 結果, アマテラスのガイド管は, J-PARC センター (日本), Mirrotron (ハンガリー), Xenox （フランス）それぞれで製作されたミラーを組み 合わせた「国際的」なものになった.

\section{4. 検出器}

アマテラスは, 検出器として 1 次元の位置敏感 型検出器を用いている. 検出器の直径は 1 インチ であり, 長さは $3 \mathrm{~m}$, ガス圧は 10 気圧である. 長 尺の検出器を円筒状に配置する検出器の設置の仕 方は, もっとも効率よく検出器の見込む立体角を

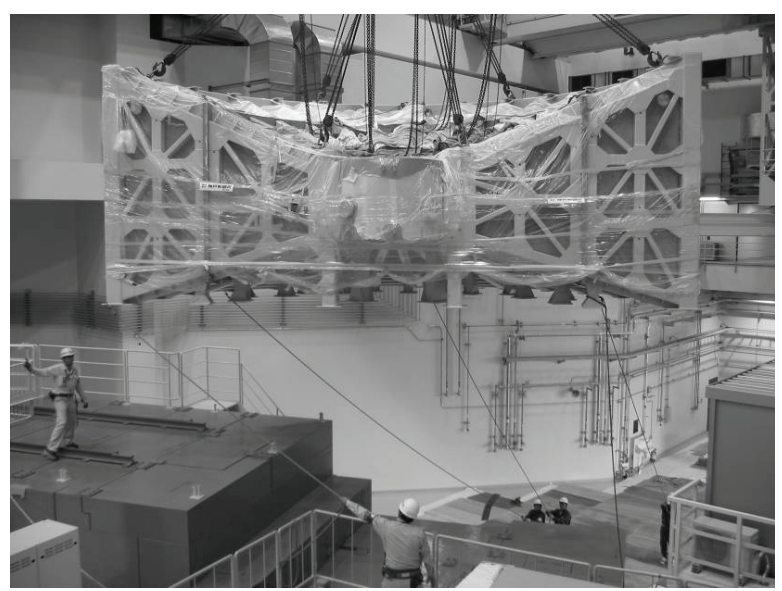

Fig.4 The scattering chamber of AMATERS being carried in MLF experimental hall. 


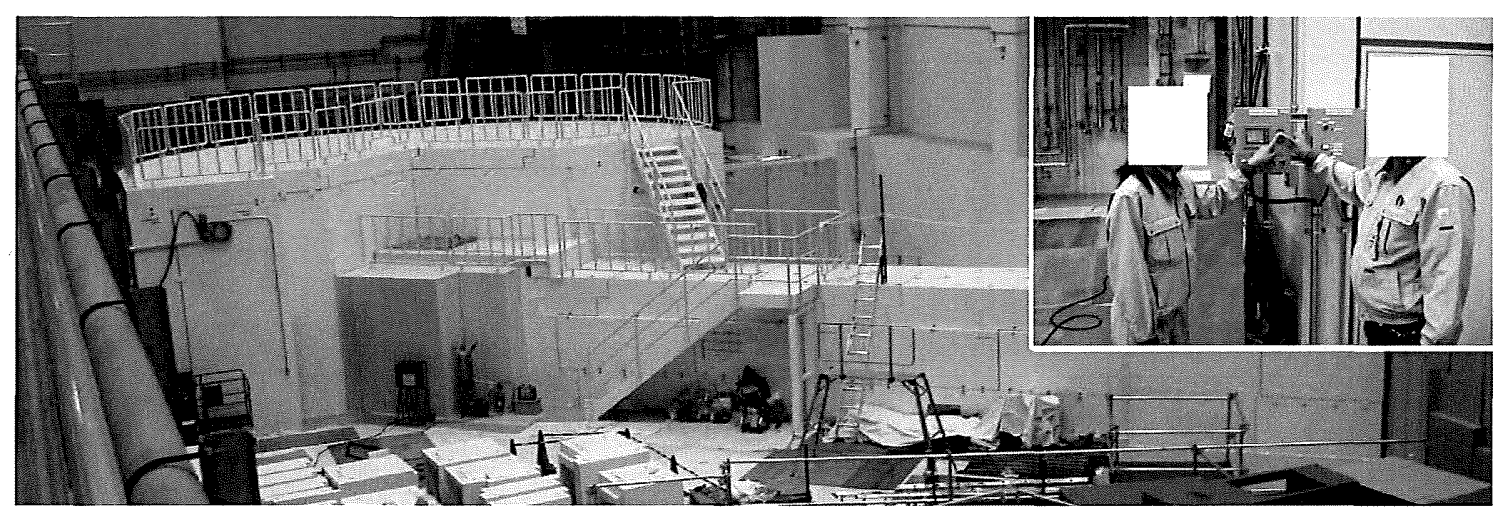

Fig.5 AMATERAS opened its beam shutter for the first neutron beam on 27 May, 2009.

大きくする配置[4]として，ILL やISIS，そして， MLF でも多くの新しいチョッパー型分光器で採 用されているが, アマテラスでもこれに倣った。 これらの検出器は, 全て真空槽内に設置されるた め, 検出器端部に真空の取り合いを持ち, リード アウト部分だけが大気に曝されるようなコネクタ 一を装備している.アマテラスは, 32 本毎合計で 14 個の検出器バンクを持つ. それぞれの検出器バ ンクの間は，奥行き $1 \mathrm{~m}$ のカドミウムで被覆され た仕切り板で区切られている. 現在, アマテラス は 266 本の検出器の調達が完了しており， 8 バン ク分の全てと 1 バンク分の 1 部が埋められ, 水平 面内で $4.7^{\circ} \sim 111.7^{\circ}$ の範囲をカバーしている.

\section{5. 遮蔽体}

アマテラスの遮蔽体は, 他の分光器同様, 鉄, ステンレス，コンクリート，ホウ酸レジン等から 作られている. 特に. 検出器を備えた真空散乱槽 が納められる分光器室遮蔽体の内側には, (株) フ ジタが開発したボロンモルタルが使用されている。 これは, $\mathrm{B}_{4} \mathrm{C}$ を高濃度（アマテラスの場合は、重 量比で 25\%) で含むモルタルで，通常のモルタル と同様の打設性状を持つ.アマテラスでは，バッ クグラウンド低減のため, 通常施されるホウ酸レ ジン等の内張の代わりに, これを $35 \mathrm{~mm}$ 厚のパネ ルに加工し分光器室遮蔽体を構成するプレキャス トコンクリートの内側に貼り付けて使用している. 総体としての遮蔽体の製作コストは下げることが でき，仕上がりも美しいものとなった。

\section{3. アマテラスのコミッショニング}

2006 年度から開始されたアマテラスの建設は, 2009 年春に無事完了した. 2009 年 5 月 27 日には, アマテラスは初の中性子ビームを受け入れた。 以 後, 2009 年 11 月末までの 40 日弱の期閒に, 検出 器調整, チョッパーシステム調整, 試料位置のビ ームの評価, バックグラウンド調查と対策, 試験 測定といった実ビームを使った機器調整（コミッ ショニング）を行ってきた．まだまだコミッショ ニングは完全ではなく, 分光器の性能を完全に引き 出すには至っていないが，それでもアマテラスはそ の片鱗を見せ始めている. Fig. 6 は, $\gamma$-ピコリン-Nオキシドの粉末試料を測定したものである，最下流
のNo. 2 高速ディスクチョッパーのみを $10 \mathrm{~mm}$ スリ ツト, $300 \mathrm{~Hz}$ で回転させた場合, 及び, 最上流の No. 1 高速ディスクチョッパーを同時に $300 \mathrm{~Hz}$ で回 転させてパルス整形を行った場合で，2 台の低速デ イスクチョッパーで 40,000 80,000 $\mu$ 秒の第 2 フレー ムを切り取っている. $E_{\mathrm{i}}$ について $3 \mathrm{meV}$ から $1 \mathrm{meV}$ まで複数のデータが取得できており，それぞれ独立 に解析可能である. RRMにより複数の $E_{\mathrm{i}}$ を入射さ せることで，異なる複数の分解能での測定が一度 に行えることは，緩和時閒の測定等，アマテラス が範囲に捉えるエネルギ一領域で期待される測定 にとって大きな魅力となるであろう．非干渉性散 乱のピークから, 弾性散乱位置での分光器の分解 能が見込まれる. No. 1, No. 2 両方の高速ディスク チョッパーを回転させることでパルス整形が実現 され, 結合型減速材由来のテールが綺麗に整形さ れているのが分かる.また, $\Delta E / E_{\mathrm{i}}$ も $1.1 \%$ 達成し， $12 \mu \mathrm{eV}$ の分解能が得られている. なお, この測定 で用いられた試料の直径は $10 \mathrm{~mm}$ で，この分解能 の領域では試料の大きさからくる飛行時間の摇ら ぎが装置本来の分解能に対して無視し得ない。も う少し注意樑い試料サイズを選択すれば，現状で もさらに高い分解能が実現されていることが確認 できるであろう。メチル基の回転のトンネル励起 が 4 本とも綺麗に観測できており，その励起エネ ルギーは，過去の測定結果[5]と一致する.

\section{4. アマテラスの今後}

冷中性子ディスクチョッパー型分光器・アマテ ラスは，一応の完成を見た。また，2009 年の 12 月からは，限られた日数ながら，一般課題の受け 入れも開始している。しかしながら，コミッショ ニングはまだまだ途上であり，きちんとした性能 を出して実験を行うためには，残された作業が多 い. また，機器のいくつかもまだ未整備である. ユーザーの方々にはご迷惑をおかけするが，これ らは, ビームタイムを割り当てられた一般課題の 実施と平行しながら，我々装置グループの努力で 早急に対応していきたい，また，装置本体以外に も現在標準的な $4 \mathrm{~K}$ の冷凍機しかない試料環境装 置の整備についても課題である.データ解析用の ソフトウェアについても，用意されている基本的 な部分からさらに個々の研究に合わせて必要とさ 
$\gamma$-Picoline-N-Oxide (powder) $1.1 \mathrm{~g} T=4 \mathrm{~K}$
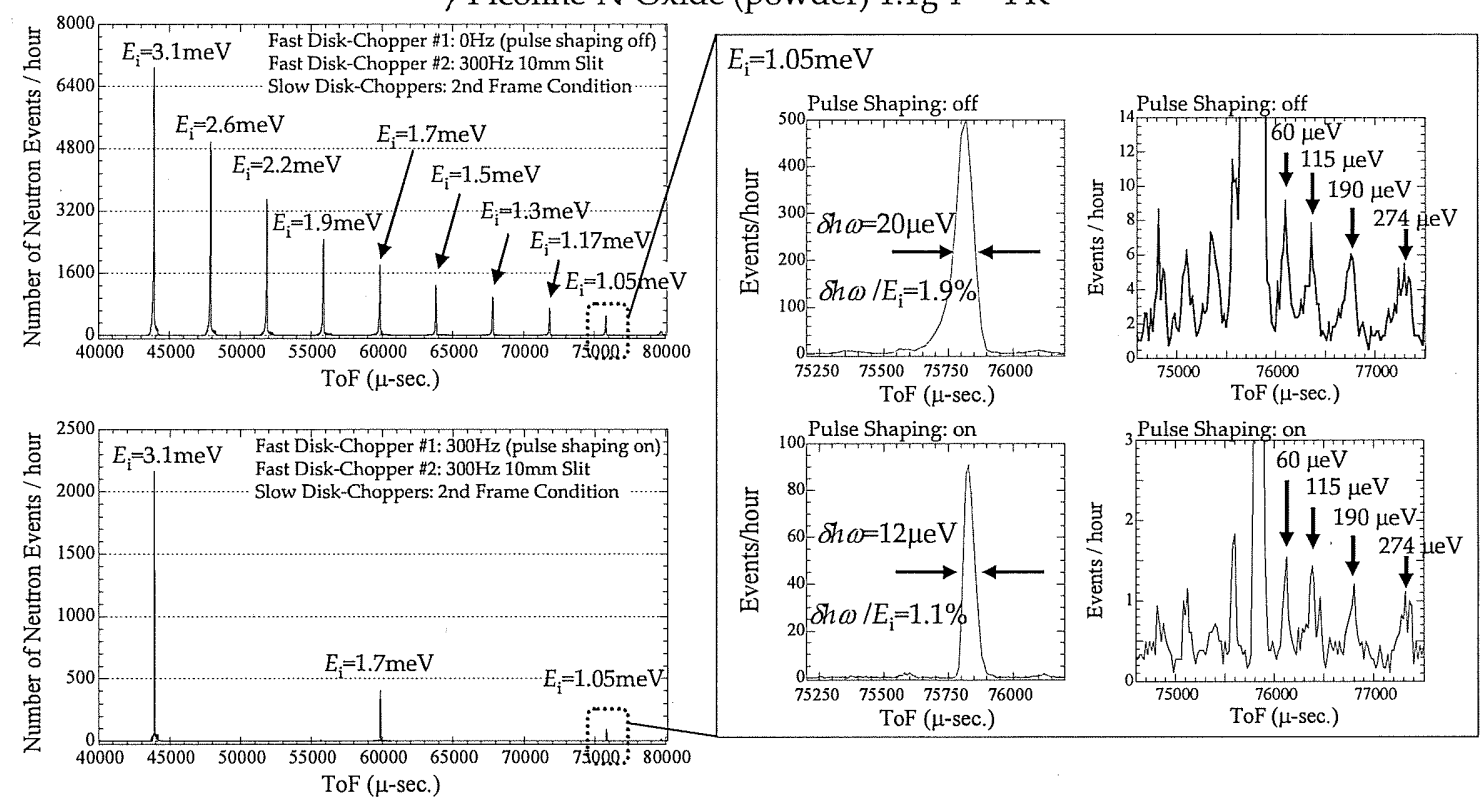

Fig.6 Observed spectrum from $\gamma$-Picoline-N-Oxide powder measured on AMATERAS at $100 \mathrm{~kW}$ operation.

れる部分については今後の整備である。これらの 部分については, アマテラスを使ってくださるユ 一ザーの方々とも協力して整備を進めていけない かと考えている。.さらに，アマテラスは，3 組の 高速ディスクチョッパーと 2 組の低速ディスクチ ヨッパーについて多彩な運転の設定が可能であり， 極めて実験の自由度が高い. MLF で標準化された イベントモードによるデータ測定と組み合わせる ことで，当初，我々が想定していなかったような アマテラスの使い方もあり得る.このような部分 も含めて, 我々装置関係者の他にアマテラスを使 ってくださるユーザーも含めてみんなでこの分光 器を良いものに仕上げていければいいと考えている.

謝辞

アマテラスの検討, 関連機器の開発, 建設, コ ミッショニングには，多くの関係者が関わってい る.これらアマテラスの実現に関わっていただい た方々，現在の運転，維持を支えていただいてい る方々に感謝しつつその名前を挙げたい，梶本亮 一 (J-PARC), 中村充孝 (同), 稲村泰弘 (同), 脇本秀一 (J-PARC, 原子力機構), 長壁豊隆 (同), 柴田薫 (J-PARC), 高橋伸明 (同), 曽山和彦 (同), 丸山龍治 (同), 相澤一也 (同), 鈴谷賢太郎 (同), 鈴木淳市 (同), 中谷健 (同), 前川藤夫 (同), 及 川健一 (同), 原田正英 (同), 吉田登 (同), 田中 浩道 (同), 岩橋孝明 (同), 神原理 (同), 加倉井 和久 (原子力機構), 佐藤卓 (東京大学), 伊藤晋 一 (KEK), 目時直人 (原子力機構), 吉田勝彦 (神 戸製鋼所)，仁井田浩二(高度情報科学技術研究機 構), Ferenc Mezei (ハンガリー科学アカデミ一), Ruep E. Lechner，新井正敏（J-PARC).
参考文献

[1] K. Nakajima et al., J. Neutron Res. 15 13-21 (2007).

[2] M. Nakamura et al., J. Neutron Res. 15 31-37 (2007).

[3] R. Kajimoto et al., J. Neutron Res. 16 81-86 (2008).

[4] R. E. Lechner, J. Neutron Res. 16 23-29 (2008).

[5] S. Ikeda et al., J. Phys. Soc. Jpn. 60 3340-3350 (1991). 